\title{
Psychosocial Theories and Pain Management Practices: A Review of Empirical Research
}

\section{Bashar I. Alzghoul}

Ph.D Student, Universiti Utara Malaysia, bashar-esam@hotmail.com

\author{
Nor Azimah Chew Abdullah
}

DrPH, Universiti Utara Malaysia, norazimah@uum.edu.my

\author{
Doi:10.5901/mjss.2015.v6n6s2p60
}

\section{Abstract}

Context: A number of psychosocial theories have been developed to predict, explain, and change health behaviors. The previous studies were concerned about the pain management practices based on various underpinning theories. Some of these studies utilized the Theory of Reasoned Action and the Theory of Planned Behavior. Furthermore, other pain management studies used the KAP model to assess the pain management practices. Objectives: the aim of this article is to determine the most appropriate underpinning theory to assess the pain management practices. Methods: the utilized models in pain management topic are outlined in turn, their similarities and differences are noted, and common criticisms are discussed. Results and Conclusion: the reciprocal determinism theory is the most suitable underpinning theory to assess the nurses' practices regarding pain management. Future studies should focus on the application of the reciprocal determinism theory to assess the pain management practices.

Keywords: pain management, psychosocial theories, personal factors and environmental factors

\section{Introduction}

Pain management deficiency is a common clinical problem among hospitalized patients, resulting in many significant consequences such as psychological, physiological and financial consequences (Zhang et al., 2008). Thus, the research attention has focused on the factors that lead to the inadequate pain management.

The previous studies which concerned about the pain management practices utilized various underpinning theories, including the Theory of Reasoned Action (TRA), the Theory of Planned Behavior (TPB) and the KAP model.

Discussion about the relative contribution (in variance explained terms) of different variables occurs frequently in the study of problems in all the social sciences. Among these studies, investigators often rely on variance explained to help decide which theory is 'better' (Fichman, 1999).

In pain management area, the Theory of Reasoned Action (TRA) and Theory of Planned Behavior (TPB) explained $21 \%$ of the variation in nurses' intention to assess patients' pain (Nash, Edwards \& Nebauer, 1993). Jurgens (1996) found that nearly $50 \%$ of the variance in behavioral intention to administer morphine was accounted for the TPB determinants. Also, Edwards et al. (2001) utilized the TPB and they found that around 40\% of the variation in intention was accounted for by the TPB determinants. Consistently, Weber, Dwyer and Mummery (2012) revealed that the constructs of the TPB explained $26 \%$ of the variance in the intention to administer morphine.

On the other hand, the KAP model explained $16 \%$ of the variation in nurses' practices regarding pain management (Basak, 2010). Also, Hossain (2010) revealed that the determinants of the KAP model only explained $1 \%$ of the pain management practices. While the previous findings are of value, it is equally important to continue to explore factors contributing to the unexplained variation in pain management practices through utilizing other underpinning theory.

The aim of this article is to determine the most appropriate underpinning theory to assess the pain management practices. The utilized models in pain management topic are outlined in turn, their similarities and differences are noted, and common criticisms are discussed.

\section{Theory of Planned Behavior}

The theory of planned behavior (Ajzen, 1985; Ajzen, 1991) is a widely utilized theory in the healthcare studies, especially when predicting or when assessing the nursing practices (Beduz, 2012; Côté, Gagnon, Houme, Abdeljelil \& Gagnon, 
2012; Haktanir, 2011; Hassan, Wahsheh \& Hindawi, 2009; Javadi, Kadkhodaee, Yaghoubi, Maroufi \& Shams, 2013; Malo, Neveu, Archambault, Émond \& Gagnon, 2012). This theory was developed from the theory of reasoned action (Azjen \& Fishbein, 1980) with little differences between them.

By comparing these theories, the theory of reasoned action is appropriate to predict the optional behaviors. However, the theory of planned behavior is not limited to just predicting the optional behavior, but also the behavior which is not completely under an optional control (Ajzen, 1991). The theory of reason action explained the relation between the attitude towards the behavior, subjective norm and the intention to do the behavior (Azjen \& Fishbein, 1980). After that in 1987, Ajzen suggested to add one variable to this model, which is perceived behavioral control to assess and predict the behavior which is not completely under an optional control.

According to the theory of planned behavior (Ajzen, 1985; Ajzen, 1991), the behavioral intention is defined as the persons' thought of self-readiness to perform the behavior, and it is the best predictor of the actual behavior. Also, based on this theory, the intention to perform the behavior is determined by three factors; attitude towards the behavior, subjective norm and perceive behavioral control.

Both behavioral theories; the theory of planned behavior (Ajzen, 1985; 1991) and the theory of reasoned action (Ajzen \& Fishbein, 1980) share the same definitions in terms of attitude and subjective norm towards the behavior. They defined the attitude towards behavior as "one's general feeling of favorableness or un favorableness toward performing the behavior," and the subjective norm is defined as a perceived external favorableness from important person to perform the behavior.

The actual personal behavior may be predicted by the intention to perform the behavior and by the direct effect from the perceived behavioral control which is defined as "an individual's perceived ease or difficulty of performing the behavior under consideration" (Ajzen, 1991). In other words, perceived behavioral control can affect the actual behavior by two ways: either by dependent contribution with attitude towards the behavior and subjective norm or by independent contribution through direct link. Figure 1.1 explains the theory of planned behavior model.

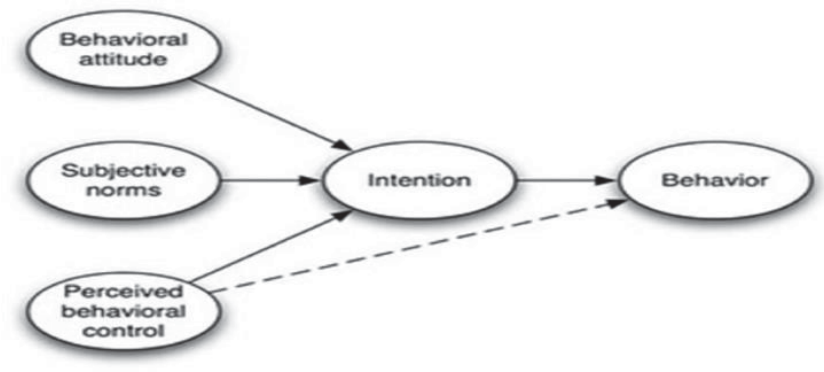

Figure 1.1: Theory of Planned Behavior Model

\subsection{Factors Affecting the Actual Behavior based on the Theory of Planned Behavior}

The Theory of Planned Behavior is a very important theory to explain and predict human behavior. Based on this theory, any behavior can be achieved by focusing on the motivational factors (intention) and the ability to perform it (perceived behavioral control). The following variables demonstrate the predictors of any behavior.

\subsubsection{Intention}

The behavioral intention is a very important factor to assess the person's tendency to perform a specific behavior. According to Lwin and Williams (2003) and Wu (2006), it is a strong indicator of the probability to carry out the behavior. There are three contributing factors in determining the person's intention which are the attitude, subjective norm and perceive behavioral control.

\subsubsection{Attitude}

The attitude towards a specific behavior is a unique and strong factor which affects the person's intention to perform such 
behavior. It has more impact on the person's intention than the subjective norm and perceives behavioral control (Ajzen, 2008). Also according to Ajzen (1991), it interprets more than fifty percent of variance in the person's intention to perform the behavior.

\subsubsection{Subjective Norm}

Armitage and Conner (2001) stated that the subjective norm is the weakest predictor of individual intention in the theory of planned behavior. This result is based on the Meta analysis of 185 studies used the theory of planned behavior as the underpinning theory. However, the result of pain management studies revealed that the subjective norm is very important predictor to the intention or performance of pain management (Al-Khawaldeh, Al-Hussami \& Darawad, 2013; Twycross, 2007).

\subsubsection{Perceived Behavioral Control}

Ajzen (1991, p.188) explained the perceived behavioral control as an extent of a person's abilities which include skills, resources and any other prerequisites to carry out the behavior. Also, Ajzen and Madden (1986) clarify it as the effect of both perceived control and self-efficacy of the behavior.

Previous studies utilize the theory of planned behavior in many specialties. According to Ajzen (April 18, 2014) more than 1200 studies used this theory. These studies' results support the theory's suggestions in the prediction of behaviors such as; prediction of smoking behavior (Godin, Valois, Lepage \& Desharnais, 1992), women's exercise behavior after childbirth (Godin, Valois \& Lepage, 1993) and losing body weight (Schifter \& Ajzen, 1985). In addition, this theory has also been utilized to predict classes' attendance (Ajzen \& Madden, 1986), donation of blood (Giles \& Cairns, 1995) and using child seat belt during driving (Richard, Dedobbeleer, Champagne \& Potrin, 1994). Furthermore, it predicts carrying out exercises (Blue, 1995), playing the video games (Doll \& Ajzen, 1992) and introducing complementary feeding to infants at six months old (Hamilton, Daniels, White, Murray \& Walsh, 2011). Moreover, this theory has been previously used in assessing the attitude of breastfeeding (Giles et al., 2007) and in predicting the mother's intention to vaccinate their daughters (Askelson et al., 2010).

Other studies utilized this theory to predict specific behavior in pain management. Nash et al. (1993) conducted a research on five public and private hospitals located in Australia. The result showed that the group effect of attitude towards the behavior, subjective norm and perceived behavioral control can significantly affect the nurses' intention to perform pain assessment. Also, according to this study's results, all of the previous factors can affect the intention to perform the practice dependently except for the perceived behavioral control which has a dependent and independent contribution in predicting the intentional behavior.

Also, this theory was utilized in a study conducted by Jurgens (1996) to predict the nurses' intention to administer morphine for the patient post operatively. The study's result showed that the combination of attitude towards the behavior, subjective norm and perceived behavioral control significantly predict the nurses' intention to administer morphine analgesic to the patients.

Similarly, Edwards et al. (2001) used this theory to examine the factors that influence the nurses' intention to administer opioids to relieve the patients' pain. In this study, the researchers assessed the relationship between direct and indirect attitude towards administering the opioid analgesics, subjective norm towards administering the analgesic, perceived behavioral control to administer the analgesic and the nurses' intention to administer the prescribed opioids to the patients. The respondents of this study were 446 Australian nurses. The study's result supports the ability of this theory in predicting the nurses' intention. In other words, all of the study's variables namely, the subjective norm, perceived behavioral control and attitude, have a significant relationship with the nurses' intention, but the highest effective variable in predicting the intention to administer analgesic was the perceived behavioral control.

Furthermore, Pellino (1997) conducted a research on 137 orthopedic patients from two cities in the Midwest. This study found that attitudes and subjective norms of orthopedic patients were significant predictors of their intentions to take postoperative analgesics. Conversely, this study showed that the relationship between perceived control and the patients' intentions to take medication was not significant.

Recently, this theory used by Weber et al. (2012) to assess the factors that affect the administration of morphine analgesic to the patient. The self-administered electronic questionnaires were sent to the paramedics participants in order to gather the required data. Based on the study's result, the paramedics have a strong intention towards administering the morphine to the patients. Also, they found a significant positive relationship between the subjective norm, perceived behavioral control and the paramedics' intention to administer morphine to the patients. However, the unexpected result 
in this study was the significant negative relationship between the attitude towards administering morphine by the paramedics and their intention to administer it. Table 1.1 represents the summary of the previous studies that used the Theory of Planned Behavior as the underpinning theory to assess the factors which affect the pain management.

The theory of planned behavior is an inappropriate underpinning theory for assessing the pain management practices. This owes to the fact that this theory is limited to the assessment of the optional behaviors and the behaviors which are not completely under an optional control (Ajzen, 1991). In other words, this theory is not suitable for assessing the obligatory behavior. Recently, the South African Society of Anesthesiologists [SASA] (2009) and the International Association for the Study of Pain [IASP] (2010) classified the pain management practices as an essential task and are one of patients' rights. So, the healthcare providers' intention to provide pain management practices which considered the main construct of the behavioral theories is not significant.

Table 1.1. Pain Management and Theory of Planned Behavior

\begin{tabular}{|c|c|c|c|c|c|}
\hline Author & Study title & IV & DV & Country\& sample & Result \\
\hline $\begin{array}{l}\text { Nash et al. } \\
\text { (1993) }\end{array}$ & $\begin{array}{l}\text { Effect of attitudes, subjective } \\
\text { norms and perceived control } \\
\text { on nurses' intention to assess } \\
\text { patients' pain }\end{array}$ & $\begin{array}{l}\text { Attitudes } \\
\text { Subjective norms } \\
\text { Perceived control }\end{array}$ & $\begin{array}{l}\text { Intention to } \\
\text { assess patients' } \\
\text { pain }\end{array}$ & $\begin{array}{l}\text { Australia } \\
n=59 \text { nurses }\end{array}$ & $\begin{array}{l}\text { There is a significant relationship between the set of attitude, } \\
\text { subjective norm and perceived control on the nurses' } \\
\text { intention to assess the patient pain. }\end{array}$ \\
\hline $\begin{array}{l}\text { Jurgens } \\
\text { (1996) }\end{array}$ & $\begin{array}{l}\text { Nurses' intentions to } \\
\text { administer morphine for post- } \\
\text { operative pain : an application } \\
\text { of Ajzen's theory of planned } \\
\text { behavior }\end{array}$ & $\begin{array}{l}\text { Attitude towards the } \\
\text { behavior } \\
\text { Subjective norm } \\
\text { Perceived behavioral } \\
\text { control }\end{array}$ & $\begin{array}{l}\text { Nurses' intention } \\
\text { to administer } \\
\text { morphine } \\
\text { analgesic to the } \\
\text { patients }\end{array}$ & $\begin{array}{l}\text { Canada } \\
n=149 \text { nurses }\end{array}$ & $\begin{array}{l}\text { There is a significant relationship between the combination } \\
\text { of attitude, subjective norm and perceived behavioral control } \\
\text { on the nurses' intention to administer morphine analgesic to } \\
\text { the patients. }\end{array}$ \\
\hline $\begin{array}{l}\text { Edwards et } \\
\text { al. (2001) }\end{array}$ & $\begin{array}{l}\text { Determinants of nurses' } \\
\text { intention to administer opioids } \\
\text { for pain relief }\end{array}$ & $\begin{array}{l}\text { Direct and indirect attitude } \\
\text { toward administer the } \\
\text { opioid analgesics } \\
\text { Subjective norm } \\
\text { Perceived behavioral } \\
\text { control }\end{array}$ & $\begin{array}{l}\text { Nurses' intention } \\
\text { to administer the } \\
\text { prescribed opioids } \\
\text { to the patients. }\end{array}$ & $\begin{array}{l}\text { Australia } \\
\mathrm{N}=446 \\
\text { Nurses }\end{array}$ & $\begin{array}{l}\text { There is significant relationship between attitudes, subjective } \\
\text { norm, perceive behavioral control on the nurses' intention to } \\
\text { administer opioids for the patients. } \\
\text { The highest effective factor in predicting the intention to } \\
\text { administer analgesic was perceived behavioral control. }\end{array}$ \\
\hline $\begin{array}{l}\text { Weber et al. } \\
(2012)\end{array}$ & $\begin{array}{l}\text { Morphine administration by } \\
\text { paramedics: An application of } \\
\text { the Theory of Planned } \\
\text { Behavior }\end{array}$ & $\begin{array}{l}\text { Attitude } \\
\text { Subjective norm } \\
\text { Perceive behavioral } \\
\text { control }\end{array}$ & $\begin{array}{l}\text { Paramedics } \\
\text { intention to } \\
\text { administer } \\
\text { morphine to the } \\
\text { patients with pain }\end{array}$ & $\begin{array}{l}\text { Australia } \\
\mathrm{N}=94 \text { Paramedics }\end{array}$ & $\begin{array}{l}\text { The paramedics have strong intention to administer the } \\
\text { morphine to the patients with pain. } \\
\text { There is a significant positive relationship between the } \\
\text { subjective norms, perceived behavioral control on the } \\
\text { paramedics' intention to administer morphine analgesic to } \\
\text { the patients with pain. } \\
\text { There is a significant negative relationship between the } \\
\text { attitudes toward administer morphine analgesic by the } \\
\text { paramedics and the intention to administer it. }\end{array}$ \\
\hline Pellino (1997) & $\begin{array}{l}\text { Relationships between patient } \\
\text { attitudes, subjective norms, } \\
\text { perceived control, and } \\
\text { analgesic use following } \\
\text { elective orthopedic surgery }\end{array}$ & $\begin{array}{l}\text { Attitudes } \\
\text { Subjective norms } \\
\text { Perceived control }\end{array}$ & analgesic use & $\begin{array}{l}\text { USA } \\
\mathrm{N}=137 \text { orthopedic } \\
\text { patients }\end{array}$ & $\begin{array}{l}\text { There is a significant relationship between attitudes, } \\
\text { subjective norm and the intentions of orthopedic patients to } \\
\text { take postoperative analgesics. } \\
\text { There is insignificant relationship between perceived control } \\
\text { and the intentions of orthopedic patients to take their } \\
\text { postoperative analgesics. }\end{array}$ \\
\hline
\end{tabular}

\section{Knowledge-Attitude-Practice (KAP) Model}

The knowledge, attitude and practices (KAP) model is one of the most used models in the medical field. According to Launiala (2009), this model was first used during the middle of the nineteenth century to assess the family planning and population (Launiala, 2009). The KAP model suggests that any practices (behaviors) are determined by the person's attitude towards the behaviors. Also, this model suggests that the person's attitude towards any behavior is based on the knowledge about this behavior. Figure 1.2 demonstrates the Knowledge, Attitude and Practice (KAP) model.

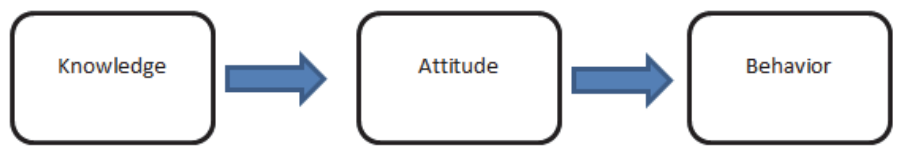

Figure 1.2: Knowledge, Attitude and Practice (KAP) Model

The KAP model has been used to assess the healthcare providers' behaviors such as the nurses' practices regarding universal precautions (Kaur, Kaur \& Walia, 2008), hand hygiene practices among healthcare students (Nair, Hanumantappa, Hiremath, Siraj \& Raghunath, 2014) and the nurses' practices regarding biomedical waste management. Also, it is used to investigate the nurses' practices regarding the spread of nosocomial infections (Kamunge, 2013), 
examine the nurses' practices regarding the screening of cervical cancer (Goyal, Vaishnav, Shrivastava, Verma \& Modi 2013) and investigate the healthcare providers' practices regarding healthcare ethics (Chopra, Bhardwaj, Mithra, Singh \& Siddiqui, 2013).

In the area of pain management, the KAP model has been utilized to assess the relationship between knowledge, attitude and nurses' practices regarding pain management (Basak, 2010; Hossain, 2010). The finding of Basak's (2010) study showed that the level of knowledge among nurses was very low and they have negative attitude towards pain management. Also, this study indicated that the nurses' practices regarding post-operative pain management were moderate. In addition, this study showed insignificant relationship between the nurses' knowledge and attitude, and practices regarding pain management.

Similarly, Hossain (2010) found that the level of knowledge, attitude and practices of pain management was at moderate level among surgical nurses. Furthermore, this study indicated insignificant relation between the study variables. Table 1.2 summarizes the previous studies that used the KAP model to assess the healthcare professionals' behavior regarding pain management.

The pain management practices are affected by personal factors (healthcare providers' factors) and environmental factors which include the healthcare system factors and patient related factors (Glajchen, 2001; Jacobsen et al., 2009; Von Roenn, 2001). On the other hand, the KAP model only covers the personal factors (knowledge and attitude). Thus, this model is not suitable for assessing the healthcare providers' practice regarding pain management.

Table 1.2. Knowledge, Attitude and Practice (KAP) Model and Pain Management

\begin{tabular}{llllll}
\hline Author & Study title & IV & DV & Country\& sample & Result \\
\hline $\begin{array}{l}\text { Basak } \\
(2010)\end{array}$ & $\begin{array}{l}\text { Knowledge and Attitudes of Nurses } \\
\text { and Their Practices Regarding Post- } \\
\text { operative Pain Management in } \\
\text { Bangladesh }\end{array}$ & $\begin{array}{l}\text { Knowledge } \\
\text { Attitudes }\end{array}$ & $\begin{array}{l}\text { Pain } \\
\text { management } \\
\text { practices }\end{array}$ & $\begin{array}{l}\text { Bangladesh } \\
n=100 \text { nurses }\end{array}$ & $\begin{array}{l}\text { Low level of pain management knowledge } \\
\text { Negative attitude towards pain management } \\
\text { Insignificant relationship between nurses } \\
\text { knowledge, attitude and their practices } \\
\text { regarding pain management }\end{array}$ \\
$\begin{array}{lllll}\text { Hossain } \\
(2010)\end{array}$ & $\begin{array}{l}\text { Nurses' Knowledge and Attitudes, and } \\
\text { Pain Management Practice of Post- } \\
\text { Operative Children in Bangladesh }\end{array}$ & $\begin{array}{l}\text { Knowledge } \\
\text { Attitudes } \\
\text { Practice }\end{array}$ & & Bangladesh & $\begin{array}{l}\text { Moderate level of knowledge, attitude and } \\
\text { practices regarding pain management } \\
\text { Insignificant relationship between all study } \\
\text { variables }\end{array}$ \\
\hline
\end{tabular}

\section{Reciprocal Determinism (Reciprocal Causation) Theory}

Reciprocal determinism is a theory which posits that any human behavior is determined by external environmental factors through social stimulus events and internal personal factors through the cognitive processes (Bandura, 1989; Bandura, 1999). These factors affect the personal behavior in an unequal strength. Bandura (1986) defined the environmental factors as social influences which include social persuasion, instruction and modeling. Also, the personal factors are explained as internal factors which include thinking, believing, and feeling of people (Bandura, 1986; Bower, 1975; Neisser, 1976). Moreover, the personal factors include cognitive, affective and biological events (Bandura, 1999).

In this model, the major relations that determine the actual practices are the relationship between the personal factors and the actual behavior, and the relationship between the environmental factors and the actual behavior. Figure 1.3 demonstrates the reciprocal determinism model.

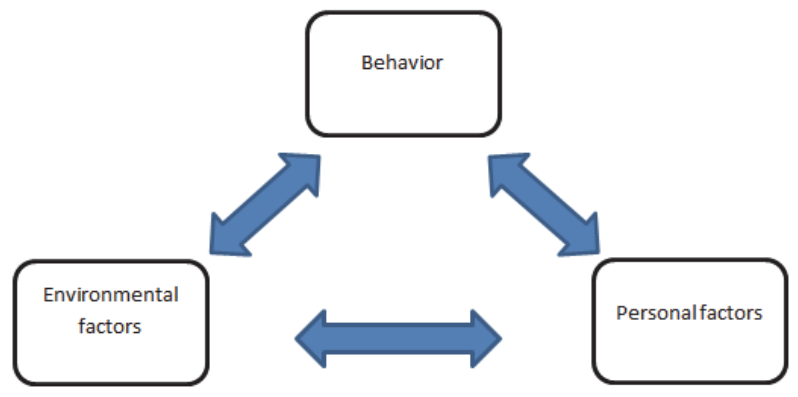

Figure 1.3: Reciprocal Determinism Model 
Many authors used the framework of reciprocal determinism to assess various behaviors. For instance, Frese, Garst and Fay (2007) assessed the effects of work characteristics (control and complexity of work) on personal initiative. In addition, Parry, Barriball and While (2015) utilized this theory to explore the factors, that contribute to Registered Nurses' medication administration's error behavior. Recently, this theory was utilized by Reiner, Niermann, Krapf and Woll (2015), to investigate the relationships between perceived stress and three health behaviors including leisure-time sedentary behavior, physical activity and food consumption.

The pain management practices are affected by personal factors (healthcare professional factors) and environmental factors which include organizational factors and patients related factors (Glajchen, 2001; Jacobsen et al., 2009; Von Roenn, 2001). The Reciprocal Determinism theory covers the personal factors and the environmental factors. Thus, this model is the most suitable in assessing the nurses' practices regarding pain management.

\section{Conclusion}

According to Ajzen (1991), the theory of planned behavior (TPB) is appropriate for assessing the optional behaviors and the behaviors which are not completely under optional control. On the other hand, pain management practices are classified as essential nurses' task and are one of patients' rights (African Society of Anesthesiologists [SASA], 2009; International Association for the Study of Pain [IASP], 2010). In other words, the nurses' intention to perform pain management is not important predictor to perform pain management practices. Therefore, the theory of planned behavior (TPB) is not an appropriate underpinning theory for assessing the pain management practices.

Otherwise, some researchers utilized the knowledge, attitude and practice (KAP) model to assess the healthcare providers' practices regarding pain management (Basak, 2010; Hossain, 2010). However, this model is only concerned about the personal determinants (knowledge and attitude). In comparison, the pain management practices are not only affected by the personal determinants (healthcare providers' factors) but are also affected by the environmental determinants such as the healthcare system factors and the patient related factors (Glajchen, 2001; Jacobsen et al., 2009; Von Roenn, 2001). Thus, the (KAP) model is not suitable for assessing the relationship between pain management practices and its determinants.

In conclusion, the Reciprocal Determinism model concentrates on the personal determinants and the environmental determinants. Therefore, the reciprocal determinism model is the most suitable theory for assessing the pain management practices.

Future studies should explore the effect of both personal factors and the environmental factors to determine the pain management practices of healthcare providers by utilizing the reciprocal determinism theory as underpinning theory.

\section{References}

Ajzen, I. (1985). From intentions to actions: A theory of planned behavior (pp. 11-39). Springer Berlin Heidelberg.

Ajzen, I. (1987). Attitudes, traits, and actions: Dispositional prediction of behavior in personality and social psychology. Advances in Experimental Social Psychology, 20(1), 1-63.

Ajzen, I. (1991). The theory of planned behavior. Organizational Behavior and Human Decision Processes, 50(2), 179-211.

Ajzen, I. (2008). Consumer attitudes and behavior. Handbook of consumer psychology, 525-548.

Ajzen, I. (April 18, 2014). Icek Ajzen, Professor of Psychology, University of Massachusetts. Retrieved from http://people.umass.edu/ aizen/

Ajzen, I., \& Fishbein, M. (1980). Understanding attitudes and predicting social behaviour. Englewood Cliffs, NJ: Prentice-Hall.

Ajzen, I., \& Madden, T. J. (1986). Prediction of goal-directed behavior: Attitudes, intentions, and perceived behavioral control. Journal of Experimental Social Psychology, 22(5), 453-474.

Al-Khawaldeh, O. A., Al-Hussami, M., \& Darawad, M. (2013). Knowledge and attitudes regarding pain management among Jordanian nursing students. Nurse Education Today, 33(4), 339-345.

Armitage, C. J., \& Conner, M. (2001). Efficacy of the theory of planned behaviour: A meta-analytic review. British Journal of Social Psychology, 40(4), 471-499.

Askelson, N. M., Campo, S., Lowe, J. B., Smith, S., Dennis, L. K., \& Andsager, J. (2010). Using the theory of planned behavior to predict mothers' intentions to vaccinate their daughters against HPV. The Journal of School Nursing, 26(3), 194-202.

Bandura, A. (1986). Social foundations of thought and action: A social cognitive theory.

Englewood Cliffs, NJ: Prentice- Hall, Inc.

Bandura, A. (1989). Social cognitive theory. In R. Vasta (Ed.), Annals of child development. Vol.

Kaur, R., Kaur, B., \& Walia, I. (2008). Knowledge, attitude and practice regarding universal precautions among nursing students. Nursing and Midwifery Research, 4(4). 
Bandura, A. (1999). A social cognitive theory of personality. In L. Pervin \& O. John (Ed.), Handbook of personality (2nd ed., pp. 154196). New York: Guilford Publications.

(Reprinted in D. Cervone \& Y. Shoda [Eds.], The coherence of personality. New York: Guilford Press.)

Basak, S. (2010). Knowledge and attitudes of nurses and their practices regarding post-operative pain management in Bangladesh (Master dissertation, Prince of Songkla University, Thailand). Retrieved from http://kb.psu.ac.th/psukb/bitstream/2010/7827/1/ 320221.pdf

Beduz, M. A. (2012). The role of attitudes, subjective norms, percieved behavioural control and context in nurses's behavioural intentions (PhD dissertation, McMaster University, Canada). Retrieved from http://digitalcommons.mcmaster.ca/cgi/viewcontent.cgi?article $=8026 \&$ context=opendissertations

Blue, C. L. (1995). The predictive capacity of the theory of reasoned action and the theory of planned behavior in exercise research: An integrated literature review. Research in Nursing \& Health, 18(2), 105-121.

Chopra, M., Bhardwaj, A., Mithra, P., Singh, A., \& Siddiqui, A. (2013). Current status of knowledge, attitudes and practices towards health care ethics among doctors and nurses from Northern India-A multicenter study.

Côté, F., Gagnon, J., Houme, P. K., Abdeljelil, A. B., \& Gagnon, M. P. (2012). Using the Theory of Planned Behaviour to predict nurses' intention to integrate research evidence into clinical decision-making. Journal of Advanced Nursing, 68(10), 2289-2298.

Doll, J., \& Ajzen, I. (1992). Accessibility and stability of predictors in the theory of planned behavior. Journal of Personality and Social Psychology, 63(5), 754-765.

Edwards, H. E., Nash, R. E., Najman, J. M., Yates, P. M., Fentiman, B. J., Dewar, A., ... \& Skerman, H. M. (2001). Determinants of nurses' intention to administer opioids for pain relief. Nursing \& Health Sciences, 3(3), 149-159.

Fichman, M. (1999). Variance explained: Why size does not (always) matter.6. Six theories of child development (pp. 1-60). Greenwich, CT: JAI Press.

Frese, M., Garst, H., \& Fay, D. (2007). Making things happen: Reciprocal relationships between work characteristics and personal initiative in a four-wave longitudinal structural equation model. Journal of Applied Psychology, 92(4), 1084.

Giles, M., \& Cairns, E. (1995). Blood donation and Ajzen's theory of planned behaviour: An examination of perceived behavioural control. British Journal of Social Psychology, 34(2), 173-188.

Giles, M., Connor, S., McClenahan, C., Mallett, J., Stewart-Knox, B., \& Wright, M. (2007). Measuring young people's attitudes to breastfeeding using the Theory of Planned Behaviour. Journal of Public Health, 29(1), 17-26.

Glajchen, M. (2001). Chronic pain: Treatment barriers and strategies for clinical practice. The Journal of the American Board of Family Practice, 14(3), 211-218.

Godin, G., Valois, P., \& Lepage, L. (1993). The pattern of influence of perceived behavioral control upon exercising behavior: An application of Ajzen's theory of planned behavior. Journal of Behavioral Medicine, 16(1), 81-102.

Godin, G., Valois, P., Lepage, L., \& Desharnais, R. (1992). Predictors of smoking behaviour: An application of Ajzen's theory of planned behaviour. British Journal of Addiction, 87(9), 1335-1343.

Goyal, A., Vaishnav, G., Shrivastava, A., Verma, R., \& Modi, A. (2013). Knowledge, attitude \& practices about cervical cancer and screening among nursing staff in a teaching hospital. International Journal of Medical Science and Public Health, 2(2), $249-253$.

Haktanir, G. (2011). Prediction of safety-related behaviour among Turkish nurses: An application of Theory of Planned Behaviour and effects of safety climate perceptions (Doctoral dissertation, Middle East Technical University, Ankara, Turkey). Retrieved from http://etd.lib.metu.edu.tr/upload/12613257/index.pdf

Hamilton, K., Daniels, L., White, K. M., Murray, N., \& Walsh, A. (2011). Predicting mothers' decisions to introduce complementary feeding at 6 months: An investigation using an extended theory of planned behaviour. Appetite, 56(3), 674-681.

Hassan, Z. M., Wahsheh, M. A., \& Hindawi, O. S. (2009). Understanding hand hygiene behavior among Jordanian registered nurses: An application of theory of planned behavior. Infectious Diseases in Clinical Practice, 17(3), 150-156.

Hossain, M. S. (2010). Nurses' knowledge and attitudes, and pain management practice of post-operative children in Bangladesh (Master dissertation, Prince of Songkla University, Southern Thailand). Retrieved from http://kb.psu.ac.th/psukb/bitstream/ 2010/7826/1/325999.pdf

International Association for the Study of Pain. (2010). IASP Declaration of Montréal. Retrieved from http://www.iasppain.org/Advocacy/ Content.aspx? ItemNumber=1821

Jacobsen, R., Liubarskienë, Z., Moldrup, C., Christrup, L., Sjogren, P., \& Samsanaviciene, J. (2009). Barriers to cancer pain management: A review of empirical research. Medicina (Kaunas), 45(6), 427-33.

Javadi, M., Kadkhodaee, M., Yaghoubi, M., Maroufi, M., \& Shams, A. (2013). Applying theory of planned behavior in predicting of patient safety behaviors of nurses. Materia Socio-medica, 25(1), 52.

Jurgens, D. W. (1996). Nurses' intentions to administer morphine for postoperative pain: An application of Ajzen's theory of planned behaviour (Doctoral dissertation, University of Saskatchewan, Saskatoon, Saskatchewan, Canada). Retrieved from http://www.collectionscanada.gc.ca/obj/s4/f2/dsk3/ftp04/nq24026.pdf

Kamunge, E. W. (2013). Exploring Knowledge, Attitudes and Practices of Registered Nurses Regarding the Spread of Nosocomial Infections.

Launiala, A. (2009). How much can a KAP survey tell us about people"s knowledge, attitudes and practices? Some observations from medical anthropology research on malaria in pregnancy in Malawi. Anthropology Matters Journal, 11, 1-13.

Lwin, M. O., \& Williams, J. D. (2003). A model integrating the multidimensional developmental theory of privacy and theory of planned behavior to examine fabrication of information online. Marketing Letters, 14(4), $257-272$. 
Malo, C., Neveu, X., Archambault, P. M., Émond, M., \& Gagnon, M. P. (2012). Exploring nurses' intention to use a computerized platform in the resuscitation unit: Development and validation of a questionnaire based on the theory of planned behavior. Interactive Journal of Medical Research, 1(2).

Nair, S. S., Hanumantappa, R., Hiremath, S. G., Siraj, M. A., \& Raghunath, P. (2014). Knowledge, Attitude, and Practice of Hand Hygiene among Medical and Nursing Students at a Tertiary Health Care Centre in Raichur, India. ISRN preventive medicine, 2014.

Nash, R., Edwards, H., \& Nebauer, M. (1993). Effect of attitudes, subjective norms and perceived control on nurses' intention to assess patients' pain. Journal of Advanced Nursing, 18(6), 941-947.

Neisser, U. (1976). Cognition and reality: Principles and implications of cognitive psychology. San Francisco: Freeman.

Parry, A. M., Barriball, K. L., \& While, A. E. (2015). Factors contributing to Registered Nurse medication administration error: A narrative review.International journal of nursing studies, 52(1), 403-420.

Pellino, T. A. (1997). Relationships between patient attitudes, subjective norms, perceived control, and analgesic use following elective orthopedic surgery. Research in nursing \& health, 20(2), 97-105.

Reiner, M., Niermann, C., Krapf, F., \& Woll, A. (2015). Stress: Personal Matter Or Family Affair? Intra-And Inter-Individual Relationships Between Stress, Physical Activity, Sedentary Behavior, And Nutrition. International Journal of Child, Youth and Family Studies, 6(1), 68-92.

Richard, L., Dedobbeleer, N., Champagne, F., \& Potvin, L. (1994). Predicting child restraint device use: A comparison of two models1. Journal of Applied Social Psychology, 24(20), 1837-1847.

Schifter, D. E., \& Ajzen, I. (1985). Intention, perceived control, and weight loss: An application of the theory of planned behavior. Journal of Personality and Social Psychology, 49(3), 843-851.

The South African Society of Anaesthesiologists. (2009). South African Acute Pain Guidelines. Southern African Journal of Anaesthesia and Analgesia, 15(6):1-120.

Twycross, A. (2007). Children's nurses' post-operative pain management practices: An observational study. International Journal of Nursing Studies, 44(6), 869-881.

Von Roenn, J. H. (2001). Are we the barrier?. Journal of Clinical Oncology, 19(23), 4273-4274.

Weber, A., Dwyer, T., \& Mummery, K. (2012). Morphine administration by paramedics: An application of the theory of planned behaviour. Injury, 43(9), 1393-1396.

Wu, S. I. (2006). A comparison of the behavior of different customer clusters towards internet bookstores. Information \& Management, 43(8), 986-1001.

Zhang, C. H., Hsu, L., Zou, B. R., Li, J. F., Wang, H. Y., \& Huang, J. (2008). Effects of a pain education program on nurses' pain knowledge, attitudes and pain assessment practices in China. Journal of pain and symptom management, 36(6), 616-627. 